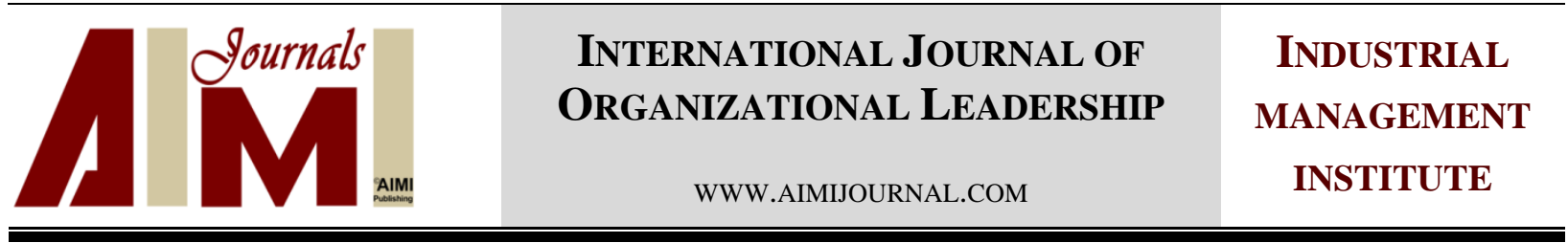

\title{
The role of intellectual capital in the development of the regional cluster
}

\author{
Tsertseil Juliya*, Ordov Konstantin \\ Plekhanov Russian University of Economics, Financial Management Department
}

\begin{abstract}
Keywords:

Intellectual Capital,

Cluster, Region,

Development, $R \& D$

\section{Received}

29 October 2016

Received in revised form

23 August 2017

Accepted

09 September 2017

Correspondence:

zerzeil8811@mail.ru

The notion of "human capital asset" implies an approach to a human who realizes all his creative potential in various fields of activity. Human capital asset plays a critical role in reduction of transaction expenses as well as transformation expenses. In the first case, institutional and social capital and in the second case, the labor, intellectual, and institutional capitals of personality are involved. Objective process of establishment and development of post-industrial economic relations predetermines increase of role and significance of intellectual capital of an individual under relative decrease of labor capital impact on activity. In its turn, this will result in increase of impact of institutional and social capitals aimed at minimization of transaction expenses of production of competitive goods, works, and services. In the current study, the matters of economic development of regions using the cluster approach based on intellectual capital growth are highlighted; petrochemical cluster of one of the Russian Federation regions - Republic of Tatarstan - is provided for illustrative purposes. Nowadays, key attention is paid to economic development of regions; special emphasis is laid on innovative development of regions based on intellectual capital's growth to receive additional competitive advantages in the age of globalization of world economic relations.
\end{abstract}

(C)AIMI Journals

Nowadays, the notion "human capital asset" implies an approach to a human who realizes all his creative potential in various fields of activity (Flamholtz, 1999). Human capital asset plays a critical role in reduction of transaction expenses as well as transformation expenses. In the first case, institutional and social capital is actually involved. Following this, in the second case, the labor, intellectual, and institutional capitals of personality are involved. Objective process of establishment and development of post-industrial economic relations predetermines the increase of the role and significance of intellectual capital of an individual under relative 
decrease of labor capital impact on activity. Thus, it will result in the increase of impact of institutional and social capitals aimed at minimization of transaction expenses for the production of competitive goods, works, and services.

Dunn (2011) mentioned that the term "intellectual capital" was introduced by Galbraith (1967) in the latter half of the nineteenth century. This term comes from "human capital asset" category. Goldin (2001) believes that the use of this category was originated by representatives of Classical (traditional) School of Mill (1885) and Petty (1677) who considered that there is influence of human factor quality on economy efficiency. The founders of human capital asset theory are considered to be American economists, namely Schultz (1961) and Becker (1975). Schultz compares a human being with physical capital used in production, pointing out that human capital asset possesses features of productive origin; it tends to be accumulated and reproduced on the renovated basis. He pointed out the investment origin of human capital asset improvement. Becker (1975) continued researches of Schultz (1961) in broader terms and he raised his researches to macroeconomic level. According to Becker (1975), human capital is the assets invested in training of an employee or a member of family but not a human himself with his knowledge and skills; as a functional element of production process”.

Goldin (2001) stated that the concept of human capital asset was developed by scientists including Ben-Porath (1967), Blaug (1962), Mincer (1981), and Fisher (1933).

Saint-Onge (1996) represented intellectual capital as human capital asset (ability of employees to meet customer needs), consumer capital (market share, degree of loyalty, and customer profitability of occupied market segments for company), and structural capital (potential of response for change of market demands). This model is a market oriented one (Flamholtz, 1999). Sullivan (2000) proposed his own model to characterize intellectual capital - as before, the basis is human capital asset (know-how and collective wisdom). Moreover, intellectual capital includes intellectual assets (special knowledge and intellectual property items), mutually supportive underlying assets (production, distribution, and sale) and structural capital (secondary resources and company infrastructure). Now, academics continue their researches in the sphere of impact of "intellectual capital" on economic development of territories. The development of management model of the company intellectual capital became particularly important. Some economists, for example, proposed management system of the company intellectual capital based on the following characteristics: type, kind, and quality (Ammann, 2010). The intellectual capital transformation is expected to promote several levels for sharing knowledge in making company value (Hofman, Maucher, Hornstein,\& den Ouden, 2012).

Porter (1998) states that globalization of market relations may lead to a decrease of transaction expenses if there are clusters in certain regions. Describing a cluster Porter (2003) outlined the decrease of transaction expenses when an employer seeks and recruits employees. But there is always a demand for such production factor as labor power in the territory of a cluster. On the other hand, the risk for hired employees' relocation decreases on virtue of geographic concentration of enterprises and organizations - participants of a cluster. On this ground, some academics (Muro \& Katz, 2010) state, that we can observe an increase of average level of salaries per one direct production worker if there is a high level of permanent employment of population in a cluster. It is explained by a high level of concentration and 
specialization of production labor force within the territory of regional industrial clusters. So we can deduce that the term "cluster" implies availability of enterprises and organizations of base (anchor) economy sector within a certain region (Ketels\&Memedovic, 2008). State development programs suppose availability of programs in the following directions including foreign investments; economical cities, industrial areas, and technological areas; production skills improvement; and support of small and medium enterprises (Keiser \&Ringlstetter, 2011).

Some economists developed and introduced definition of "regional innovational (production) cluster” as geographical concentration of interacting suppliers of production factors, business units of commercial entities, coordination centers, and associations of institutes and universities that perform their activity within special economy sector in order to increase the efficiency of regional activity. A regional cluster is characterized by the capability to implement positive synergy effect leading to an increase of innovation activity in the region, growth of salary level as compared to the industry average level.

\section{Research Questions}

The following research questions guided the study:

- What is the level of relationship between the expenses for Research and Development, R\&D (technological developments) and average level of salary within the Central Federal District?

- What is the correlation between expenses for purchase of equipment in absolute terms and quantity of used advanced innovating technologies (units) within Volga Federal District?

\section{Method}

Table 1 reflects the following kinds of regional clusters have been formed and exist within the territory of federal districts of the Russian Federation.

Table 1

Kinds of Regional Clusters Within Russian Federation

\begin{tabular}{|c|c|}
\hline Federal District & Clusters within a Federal District \\
\hline Northwestern Federal District & $\begin{array}{l}\text { Cluster of Medical, Pharmaceutical Industry and Radiation Technologies of Saint Petersburg, Saint } \\
\text { Petersburg, Leningrad region } \\
\text { Development of informational Technologies, RadioElectronics, Instrument Engineering, } \\
\text { Communication Tools, Information and Telecommunications, Saint Petersburg, } \\
\text { Ship-building Innovation Cluster of Arkhangelsk Region, Arkhangelsk Region }\end{array}$ \\
\hline Central Federal District & $\begin{array}{l}\text { Cluster of Pharmaceutics, Biotechnologies and Biomedicine (Obninsk), Kaluga region } \\
\text { Cluster "Phystech XXI' (Dolgoprudniy, Khimki), Moscow Region } \\
\text { Biotechnological Innovation Territorial Cluster of Nuclear-Physical and Nanotechnologies in } \\
\text { Dubna, Moscow Region } \\
\text { New Materials, Laser and Radiation Technologies (Troitsk), Mocow } \\
\text { "Zelenograd" cluster }\end{array}$ \\
\hline Volga Federal District & $\begin{array}{l}\text { Energy-Efficient Lighting Engineering and Intellectual Systems of Lighting Control, Mordovia } \\
\text { Sarovskiy Innovation Cluster, Nizhniy Novgorod Region } \\
\text { Nuclear-Innovational Cluster of Dimitrovgrad in Ulyanovsk Region, Ulyanovsk Region } \\
\text { Consortium “Scientific-Educational-Production Cluster “Ulyanovsk-Avia”, Ulyanovsk Region } \\
\text { Kama Innovational-Territorial-Production Cluster of Tatarstan Republic, Tatarstan Republic } \\
\text { Nizhniy Novgorod Industrial Cluster in the Sphere of Automobile Construction and Petrochemical } \\
\text { Industry, Nizhniy Novgorod Region } \\
\text { Innovating Territorial Aerospace Cluster of Samara Region, Samara Region } \\
\text { Petrochemical Territorial Cluster, Republic of Bashkortostan } \\
\text { Innovating Territorial Cluster Of Rocket Propulsion Engineering “Technopolis Noviy Zvezdniy”, } \\
\text { Perm Territory }\end{array}$ \\
\hline Ural Federal District & Titanium Cluster of Sverdlovsk Region, Sverdlovsk Region \\
\hline Siberian Federal District & $\begin{array}{l}\text { Pharmaceutics, Medical Equipment and Informational Technologies in Tomsk Region, Tomsk } \\
\text { Region } \\
\text { Complex Reprocessing of Coal and Industry-Related Waste, Kemerovo Region, } \\
\text { Cluster of Innovating Technologies Closed Administrative-Territorial Unit in Zheleznogorsk, }\end{array}$ \\
\hline
\end{tabular}




\begin{tabular}{ll} 
& Krasnoyarsk Territory \\
& Innovating Cluster of Informational and Biopharmaceutical Technologies of Novosibirsk Region, \\
& Novosibirsk Region \\
& Altai Biopharmaceutical Cluster, Altai Territory \\
\hline \multirow{2}{*}{ Far East Federal District } & Innovating Territorial Cluster Of Aircraft Engineering And Ship-Building Of Khabarovsk Territory, \\
& Khabarovsk Territory \\
\hline
\end{tabular}

(Source: Author's Work)

The regression analysis (Schroeder, 2010) given by the author and shown in Figure 1 was to evaluate functional relationship of the effective index of conditional average (the share of sold innovation products in the total volume of revenue) and the factorial index (the share of $R \& D$ organizations in the total quantity of enterprises) on the territories of innovation clusters pointed in Table 1 (Tsertseil \& Ordov, 2016a).

Figure 1 presents the R\&D organizations and volume of innovation products produced on the innovation cluster's territories in the Russian Federation.

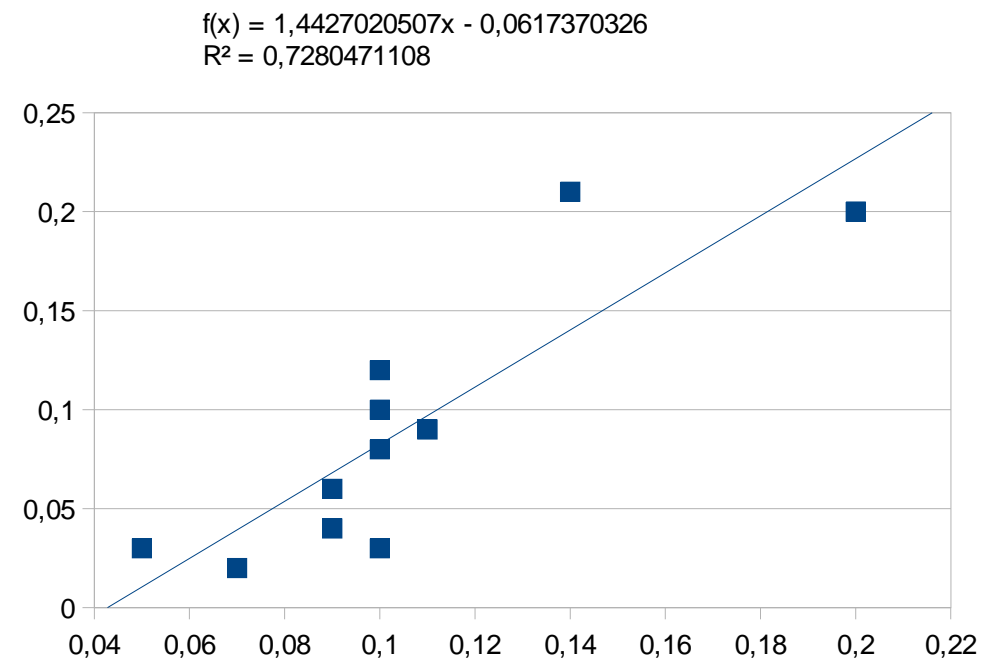

Figure 1.R \& D organizations and volume of innovation products produced on the innovation cluster's territories in the Russian Federation

The activity of these clusters within territory of federal districts has positive trends in the development of these regions. Positive trends include: the influence of scientific-and-research potential of a region (expenses for research and development, technological innovations) and social standard of living (average level of salary), the efficient process of investment in capital assets within regional clusters for the purpose of their purchase, and modernization and revamping as exemplified by the Central and Volga Federal districts, as shown in Figure 2 (Tsertseil \& Ordov, 2016b).

Figure 2 represents the relationship between the share of the innovation produce expenditures in the overall volume of expenses $(\mathrm{x})$ and the share of innovation product sales proceeds in the total volume of revenue $(y)$ on Central and Volga-region Federal districts, 2014. 


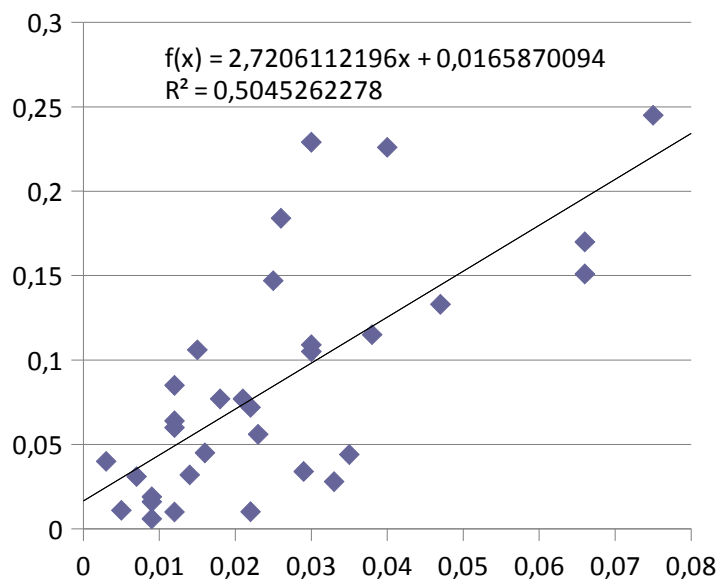

Figure 2. The relationship between the share of the innovation produce expenditures in the overall volume of expenses (x) and the share of innovation product sales proceeds in the total volume of revenue (y) on Central and Volga-region Federal districts, 2014

Central Federal District is represented by the following territories: Belgorod Oblast, Bryansk Oblast, Vladimir Oblast, Voronezh Oblast, Ivanovo Oblast, Kaluga Oblast, Kostroma Oblast, Kursk Oblast, Lipetsk Oblast, Moscow Oblast, Oryol Oblast, Ryazan Oblast, Smolensk Oblast, Tambov Oblast, Tver Oblast, Tula Oblast, and Yaroslavl Oblast. Within Central Federal District of the Russian Federation a certain correlation has been formed which reflects close relationship between level of expenses for technological innovations (x) in absolute terms and average monthly level of salary (y), determination coefficient is equal to $66 \%$ as shown in Figure 3.

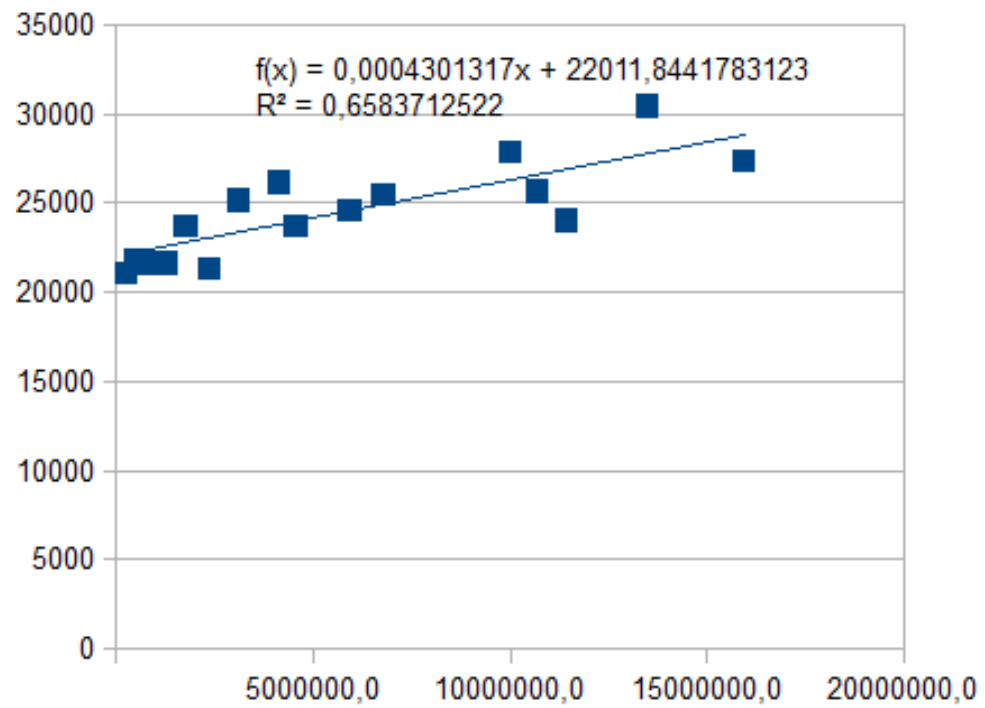

Figure 3.Correlation between expenses for Research and Development (technological developments) and average level of salary within the Central Federal District (Source: author's work)

\section{Results}


Cluster development theory is a synthesis of the concepts of the production location and the competitive advantages of the company, which entails the development of cluster structures in various sectors of the region. Therefore, there is a need to build an appropriate corporate strategy of companies - participants of the cluster, which will ensure the growth of enterprise value in the post-industrial economy. We think that the practical use of the cluster approach to support the company's value growth in a competitive environment can be used as a tool for regional economic development. The developed model of the regional cluster, located on the territory of the Volga Federal District, the Republic of Tatarstan is formed under the influence of the cluster theory. Big chemical complexes are concentrated on the territory of the Volga Federal District. They represent the largest anchor enterprises of the chemical industry such as OJSC “NOVATEK”, OJSC “Tolyattiazot”, Holding “Sibur”, CJSC “Volgopromkhim”, OJSC "VolzhskyOrgsintez", CJSC "Kuibyshevazot”, OJSC "Plant of household chemicals”, OJSC "Nizhnekamskneftekhim”, OJSC “Kazanorgsintez”, OJSC "Nizhnekamsk Industrial carbon plant”, OJSC "Nizhnekamskshina", based on their own raw material base. The petrochemical cluster has been established in Volga Federal district, its anchor (basic) enterprises are located within the territory of Tatarstan Republic. This cluster includes OJSC "Tatneft", OJSC "Tatneftekhiminvest-holding”, OJSC “Taif-NK”, OJSC "Nizhekamskneftekim”, OJSC "Nizhnekamskshina”, OJSC "L.Ya. Karpov Chemical Plant”, OJSC "Nizhnekamsktekhuglerod”, OJSC “Kazan Synthetic Rubber Plant”, OJSC "Nefis Cosmetics”, and many others as shown in Figure 4 which depicts the key participants of petrochemical regional cluster.

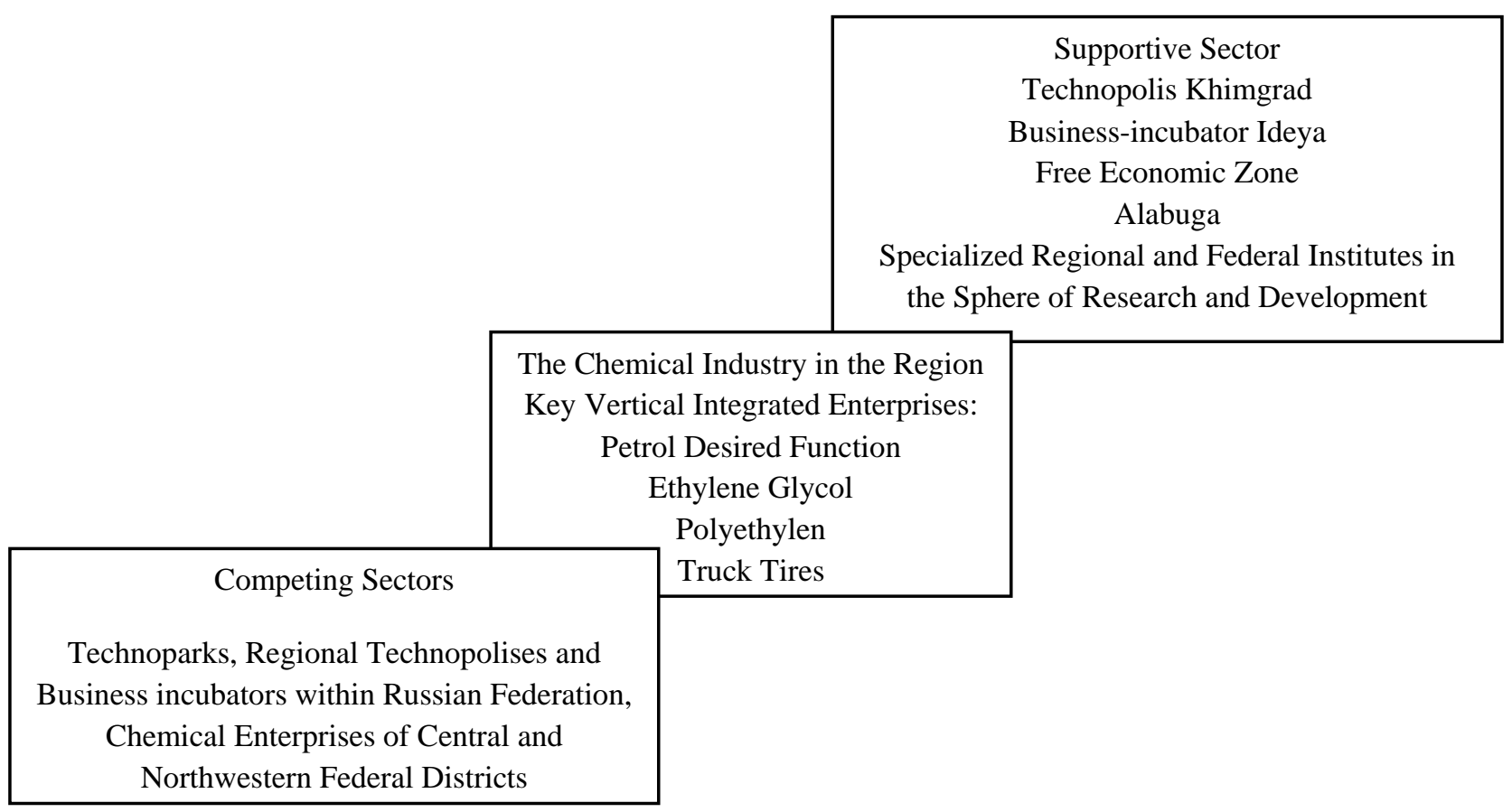

Figure4.Key participants of petrochemical regional cluster

According to Porter (2008), based on branching-off groups we can refer the following to the related enterprises: OJSC "Kazan Synthetic Rubber Plant”, OJSC “Nizhekamskneftekim”, OJSC “Nizhnekamskshina”, OJSC “L.Ya. Karpov Chemical Plant” as well as plants located 
outside Republic of Tatarstan, namely "Starolen” LTD in Budenovsk (polyethylene production), Yaroslavl Synthetic Rubber Plant, Tomsk Synthetic Rubber Plant. These enterprises of allied industries are located in Bashkortostan, Mari El, Mordovia, Udmurtia, Chuvashia, Perm Krai, Kirov Oblast, Nizhniy Novgorod Oblast, Orenburg Oblast, Penza Oblast, Samara Oblast, Saratov Oblast, and Ulyanovsk Oblast.

Figure 5 exhibits the correlation between expenses for purchase of equipment in absolute terms and quantity of used advanced innovating technologies (units) within Volga Federal District.

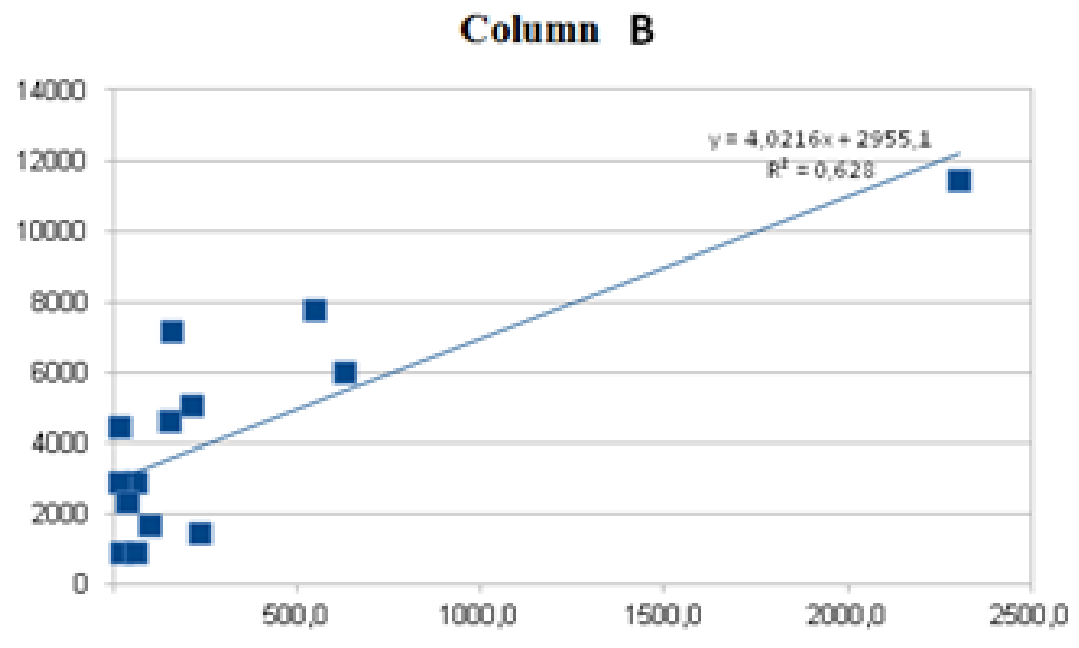

Figure 5.Correlation between expenses for purchase of equipment in absolute terms and quantity of used advanced innovating technologies (units) within Volga Federal District

Within regional clusters of Volga Federal district of the Russian Federation the correlation has been formed which reflects close relationship between level of expenses to purchase equipment (x) in absolute terms and quantity of used advanced innovating technologies (y), determination coefficient is equal to $63 \%$ as shown in Figure 4. In this particular case we see that investments in capital assets result in implementation of advanced innovating technologies that in future it should influence the efficiency of production within territory of these regions and increase of relative share of innovating products in total production volume.

\section{Discussion and Conclusion}

In modern production conditions clusters provide the implementation of two opposite processes, namely horizontal competitiveness between homogeneous enterprises and vertical cooperation among enterprises of the same process chain. It is possible since these processes take place in different measurements and among different economic entities. The peculiarity of formation of chemical cluster within Volga Federal District is availability of verticallyintegrated chain of anchor enterprises that form the core of chemical cluster. Products manufactured by these enterprises are the "intermediary production of semi-products" which 
then will be used by enterprises and organizations in allied and supporting industries of all federal districts. Based on obtained correlation, clusters provide for and stimulate active implementation of technological innovations and promote economic development of the whole federal district.

Clusters feature a new type of space regional organization of markets and vertically integrated structures as well as an alternative method to organize chains of value creation. As compared to market transactions between long-distance sellers and buyers, the proximity of companies and institutes located within the same geographical space, high density of production cooperation and frequency of repeated transactions between them increase level of coordination and confidence between cluster participants. Clusters feature the association of production and social systems as well as an instrument to implement strategy of regional industrial development. Industrial regional cluster can be determined as geographically delineated concentration of interdependent business with active channels for business transactions, communication and interaction and which (business) share common possibilities and risks. Dynamic development of enterprises and organizations - cluster members is the key factor of positive synergy effect of a cluster.

\section{References}

Ammann, E. A. (2010). Hierarchical modelling approach to intellectual capital development. Electronic Journal of Knowledge Management, 8(2), 181-191.

Becker, G. (1975). Human Capital. Chicago: University of Chicago Press.

Ben-Porath, Y. (1967). The Production of human capital and life cycle of earnings. The Journal of Political Economy, 75(4), 352-365.

Blaug, M. (1962). Economic theory in retrospect( $4^{\text {th }}$ ed.).Cambridge: Cambridge University Press.

Dunn, S. P. (2011). The economics of John Kenneth Galbraith: Introduction, persuasion, and rehabilitation. Cambridge: Cambridge University Press.

Fisher, I. (1933). The debt-deflation theory of great depressions. Econometrica, 1(4), 337-357.

Flamholtz, E. G. (1999). Human resource accounting: Advances in concepts, methods, and applications ( $3^{\text {rd }}$ ed.).Boston, London: Kluwer Academic Publishers.

Galbraith, J.K. (1967). The new industrial state. Boston: Houghton Mif- flin Company.

Goldin, C. (2001). The human capital century and American leadership: Virtues of the past. Journal of Economic History, 61, 263-291.

Hofman, E., Maucher, D., Hornstein, J., \& den Ouden, R. (2012). Capital equipment purchasing. Optimizing the total cost of CapEx sourcing (Professional Supply Management). London, New York: Springer.

Keiser, S., \&Ringlstetter, M. (2011). Strategic management of professional service firms: Theory and practice. Heidelberg: Springer.

Ketels, H. M., \&Memedovic, O. (2008). From clusters to cluster-based economic development. International Journal of Technological Learning, Innovation \& Development, 1(3), 375-392.

Mill, J.S. (1885). Principles of political economy. New-York: D. Appleton and Company.

Mincer, J. (1981). Human capital and economic growth(Working Paper No. 803). Retrieved from National breau of economic research website: http://www.nber.org/papers/w0803.pdf

Muro, M., \& Katz, B. (2010). The new “cluster moment”: How regional innovation clusters can foster the next economy.Washigton, DC: The Brookings Institution.

Petty, W. (1677). The economics writings of Sir William Petty. Cambridge: Cambridge University Press.

Porter, M. E. (1998). Clusters and the new economics competition.Harvard Business Review, 76(6), 77-90.

Porter, M. E. (2003). The economic performance of regions. Regional Studies, 37(6/7), 549-578. 
Porter, M. E. (2008). On Competition, updated and expanded edition.Boston: Harvard Business School Publishing.

Saint-Onge, H. (1996). Tacit knowledge the key to the strategic alignment of intellectual capital. Planning Review, 24(2), 1016.

Schroeder, D. A. (2010). Accounting and causal effects: Econometric challenges. Springer.

Schultz, T.W. (1961). Investment in human capital. The American Economic Review, 51(1), 1-17

Sullivan, P.H. (2000). Valuing intangibles companies: An intellectual capital approach. Journal of Intellectual Capital, 1(4), 328-340.

Tsertseil, J., \& Ordov, K. (2016a). The Development of the regions on the cluster's territory: evidence of central and volgaregion federal districts on the territory of Russian Federation. GSTF 2016: Proceedings of the 6th Annual International Conference on Qualitative and Quantitative Economics Research, Singopure, 9-15.

Tsertseil, J., \& Ordov, K. (2016b). Cluster's innovation development through the territory of the regions. Paper presented at the Third International Conference of Political Science, International Relations and Sociology, Antalya, Turkey. 